\title{
THE LOST GARDEN OF ACEH
}

\author{
Muhammad Naufal Fadhil*, Nurul Fakriah** \\ *) Department of Architecture, Universitas Indonesia, Jawa Barat, Indonesia \\ **) Department of Architecture, Universitas Islam Negeri Ar-Raniry, Banda Aceh, \\ Indonesia \\ e-mail: nflfadhil@gmail.com
}

\begin{abstract}
In the seventeenth century AD, the Sultanate of Aceh, under the leadership of Sultan Iskandar Thani, made a manuscript entitled Bustanussalatin. This manuscript contains the story of the creation of the universe, the relationship between God and man, the lineage of the sultans of Aceh, and a small section about the royal Garden called Taman Ghairah. The existence of this Garden is still questionable, but scholars who research this garden associate three buildings nearby the former royal palace as a remnant of this Garden. This paper questions whether this Garden was built or not and when it was built, and its loss. Through literature review and archival research, this paper tries to trace the presence and disappearance of this Garden. The Bustanussalatin manuscript provides information on the development of this Garden during the reign of Iskandar Thani. Meanwhile, researchers believe that this Garden was already built during the Iskandar Muda era. Portuguese maps provide information that this Garden did not exist in the sixteenth century. In contrast, a map of the Netherlands in the nineteenth century before the Dutch Aceh War also does not depict this garden. This research proposes that this Garden was likely built during the reign of Iskandar Muda and was lost before the Dutch military aggression to Aceh.
\end{abstract}

Keywords: Taman Ghairah, Bustanussalatin, Aceh Historical Garden

\section{INTRODUCTION}

The Seventeenth-century Islamic Kingdom of Aceh has built a garden which was known as Taman Ghairah. The existence of this Garden is written in the Bustanussalatin Manuscript, the earliest text mentioning this Garden that this study could find. This book was written by Nur ud-Din ar-Raniry. He wrote, "it was in the reign of His Majesty, who built a stunning garden, about a thousand fathoms wide. He planted various flowers and fruits (in it). The sultan's garden was called Taman Ghairah" (Iskandar 1966). This text informed that the Taman Ghairah was built during Sultan Iskandar Thani, who ordered the Bustanussalatin Book, where the Garden was mentioned. Lombard (1986) suspected that his predecessor, Sultan Iskandar Muda, 
had initiated the construction of this Garden in advance by turning the river towards the palace. From Bustanussalatin (Iskandar 1966) and Denys Lombard (1986), precise information has been obtained that this Garden was built during Sultan Iskandar Muda and Sultan Iskandar Thani, or in the mid-early 17th century.

According to the book of Bustanussalatin, the Taman Ghairah was a vast garden with various flowers, fruit plants, edifices, and landscape features inside it. However, Taman Ghairah in the present-day of Banda Aceh City is only a pseudo-idea that is not well-known. The only remnants of this historic Garden that still survive are Gunongan, Kandang, Pintô Khôp, Krueng Daroy River, and a white stone called Leusong. Other garden objects have been destroyed, and traces of archaeological remains have not been found other than the five relics that have been mentioned earlier.

Since the remnants of this Garden are very few, the existence of this Garden is questionable. The information of when the Garden was built is also contradictive (AS, 2014). Even though many scholars have published their work about this Garden (Harun, 2004; Wulandari et al., 2017; AS, 2014; Fadhil, 2015; Restiyadi\&Syam, 2018; Fakriah, 2021 ), the existence and the loss of the Garden is still left unknown. Arif (2014) suggests that the Taman Ghairah was destroyed after the Dutch took Banda Aceh or after the Dutch captured the palace in 1874. However, this opinion is considered weak because, in his magazine publication, he did not show the condition before the Dutch took control of the city. Thus, this study intends to examine Arif's opinion of whether Taman Ghairah disappeared after the Dutch occupation. In addition, this study will explore the idea of the Taman Ghairah and its existence and when the Garden disappeared or began to crumble by slowly analyzing maps and historical sources.

\section{RESEARCH METHODS}

This study is the architectural history research of Taman Ghairah that investigated through the literature and artefacts review. The method involved a two-phase methodology based on a critical literature study and archival research (artefacts such as maps). This research required selecting, incorporating, and elaborating the full range of literature and maps related to the Taman Ghairah Aceh.

To trace the architectural history of Taman Ghairah, the study first described the idea and physical form of Taman Ghairah. Secondly, the study analyzed several scholars' contentions around the Taman Ghairah. Lastly, the study explored, compared, and discussed the existence and disappearance of the Garden. In this part, some earlier maps were analyzed to find the presence of Taman Ghairah on those maps. This part also compares and discusses each opinion around the Garden's disappearance and then relates them to the maps. 


\section{RESULTS AND DISCUSSION}

\section{Contention Around Taman Ghairah}

The Gunongan object has sparked many debates around historians due to many versions of circulated folklore in Aceh, the story of the foreigners travelling to Aceh, and some comparisons with Hindu-Buddhist Cosmology. According to Saint PolLias, the related level of Gunongan can be defined into two stories: the more pleasing about the Sultan and the gifts for his beloved wife and another rare story as the place of judgment and the death penalty (Reid 2010). Among the two levels, the community's well-known is the first one about the Sultan and his favourite wife. The story is passed down orally in society and is written in the Hikayat Malam Dagang and Hikayat Meukuta Alam (Feener 2011).

The first story tells that Gunongan was made during the time of Sultan Iskandar Muda. After Sultan Iskandar Muda seized the Pahang Kingdom, then he married the daughter of the king. After Pahang Princess (Putroe Phang) was taken to Banda Aceh, she felt homesick because she missed her hilly hometown in Pahang. To treat her fiancé's hearth, Iskandar Muda decided to build a mountain-like structure, and a set of other urban landscapes surrounded it.

Nasruddin AS argued that the Gunongan was built during Iskandar Muda's reign. Therefore the Garden was also built during his reign because there is a similarity between the Gunongan and other construction nearby, showing that they are part of the Garden (AS 2014). An old manuscript named Hikayat Malem Dagang was also a pinpoint of previous researchers who built Gunongan. The greatness of Sultan Iskandar Muda is also mentioned in other manuscripts such as Hikayat Aceh, Hikayat Lada Sicupak, and correspondence between Sultan Iskandar Muda and the British Kingdom. AS (2014) contends that Ar-Raniry only mentioned the name of Sultan Iskandar Thani because he was the one who ordered him to write the manuscript. Also, because the previous sultan, Sultan Iskandar Muda, rejected his coming to Aceh because he opposed the doctrines that had grown in Aceh at that time. Only after Sultan Iskandar Thani ruled Aceh, Ar-Raniry was accepted and became the trusted advisor for the king (AS 2014).

Through the first story, it can be concluded that the current understanding in the Aceh Society in the Garden and Gunongan was built during the reign of Sultan Iskandar Muda. However, Djajadiningrat doubted the story. According to Djajadiningrat, it is rather hastily to conclude the development of this Gunongan in Sultan Iskandar Muda, especially in the time of Sultan Iskandar Thani. However, he believed that Gunongan already existed in Sultan Iskandar Muda (Wessing 1988).

Similarly, Lombard and Brakel questioned Putroe Phang's story and classified Gunongan as a Cosmic Mountain. Lombard mentioned that Gunongan is the most recent form of expression of Cosmic Mountain. Brakel argued that the Garden said in Bustanussalatin that surrounds it strengthens Gunongan as a Meru (Wessing 1988). The Portuguese travel record reinforces those views in Sumatra, Mark Dion, which mentioned that "a great heathen temple famous for its gold existed in Aceh before the middle of 16th century" (Wessing 1988). This object was quite similar to Gunongan because the Bustanussalatin said that Gunongan has a peak covered with Suasa, a mixture of gold and copper. 
Suppose the Garden has already existed before Islam, and it was maintained well until the Islam period. In that case, there may be similarities in the garden concept (during Islam), or there is an acceptable form of Islam by adding another form or using it for other functions. And vice versa, if Islam built the Gunongan and the surrounding gardens, then it seems that there were still old concepts preserved and represented in the form of a garden. The author's opinion is in line with Wessing's, who pointed that although Islam came to Aceh in 1205, it came through India (Hindu-Buddhist influence). There were some mixtures of Indian culture (Wessing 1988). According to Raap, there are similarities in naming the garden objects with Mughal Garden, and it is believed that some of these garden builders are Indians (Raap 1994). Moreover, even though Islam ruled in Aceh at that time, Acehnese's pre-Islamic traditions were conducted from the past and survived to these days.

\section{The Description of Taman Ghairah}

Taman Ghairah (Ghairah Garden) was the most prominent urban form built during Iskandar Thani's reign (1637-1641). Until recently, there are no primary sources except Bustanussalatin that mentioned the term Taman Ghairah. Although foreigners' sources such as Manuel Godinho de Eredia (1610), Agustin de Beaulieu (1620), and de Graff (1641) mentioned the gardens in Aceh, none of them says the name of the Garden or Taman Ghairah. The exact origin of this Garden is debatable. Still, Denys Lombard assumed that the Garden could have been developed over the reign of the sultan or the continuations of the effort of former sultans (Lombard 1986).

According to Bustanussalatin, this Garden was built by Sultan Iskandar Thani, who acted as an architect (Raniri and Iskandar 1966). Beaulieu mentioned that "The sultan gave them the design of the building that he desired, and often if the window, door, or the shape is against his instruction, the sultan will order to demolish and rebuild the building" (Reid 2010). The king maintained the quality of the buildings in his palace and city according to his tastes. Several nations of the world very likely influence this taste. Some of the countries that Bustanussalatin mentioned that influenced the formations in the Garden were Turks and Chinese. In addition, what might have influenced the sultan's taste at that time was the Acehnese traditions.

The Bustanussalatin text begins to mention Pintu Biram InderaBangsa, which in the modern toponymy is known as Pintô Khôp (Wessing 1988). This gate is the connection between Daruddunya palace (royal palace) with the Taman Ghairah (Figure 1). According to Lombard, "The Taman Ghairah can be accessed from the sultanate palace from a great gate whose top was carved (Lombard 2006). The Pintô Khôp is one of the Garden's remains that exist until nowadays. 


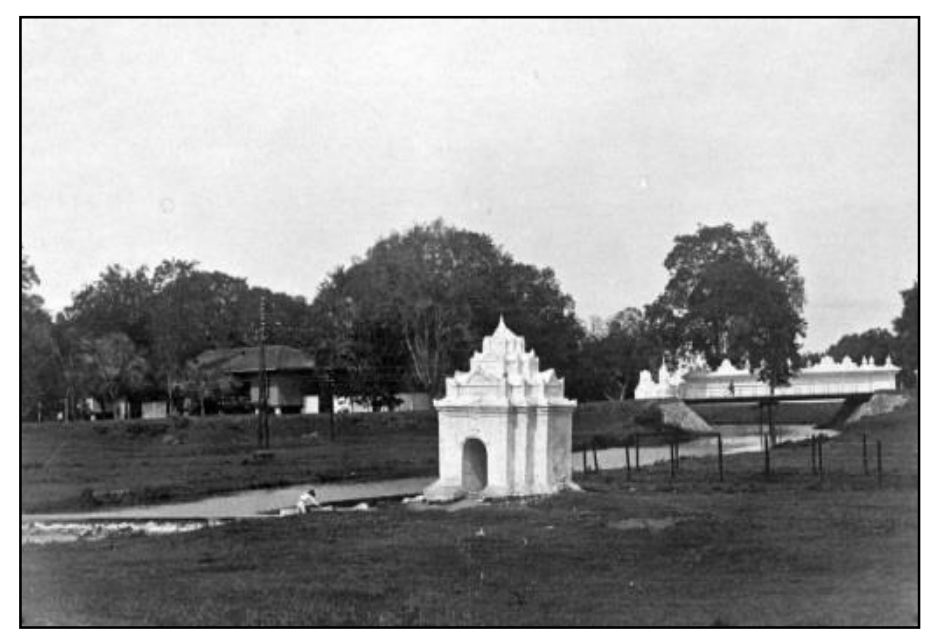

Figure 1. Pintô Khôp during colonial era source : collectie.tropenmuseum.nl, 1910-1926

The author's point is that the gate resembles the flower's petal, and its roof is three tiers with a sharp tip. In the door head, there is a type of flower ornament of different sizes. The gate's door is $150 \mathrm{~cm}$ high, making a person bow a bit when entering it.

Bustanussalatin then continues on the formation of the river in the Taman Ghairah. The river is called the Dar Ul-Isyki river, which later became more popular with Krueng Daroy. According to an English explorer, Thomas Best, this river was previously made by order of Sultan Iskandar Muda. He dammed the water and flowed it eastward to cross the Daruddunya Palace, developed (Lombard 2006). The area that was deflected by the river was in the Geuceu area, which according to Arif, the words Geuceu came from the Acehnese language, which means 'crossed out by him', which suggests that Sultan Iskandar Muda had made a scratch there, which was made a branch of the river (Arif 2014). The river that flows from the Mata Ie area diverges into two streams in the Geuceu area, Banda Aceh (behind the Baitul Musyahadah Mosque) (Figure 2). The river was called Krueng Doy (shallow river) initially because its flow was divided, while the river that crosses Gunongan and the Kraton Daruddunya area is called Krueng Daroy. 


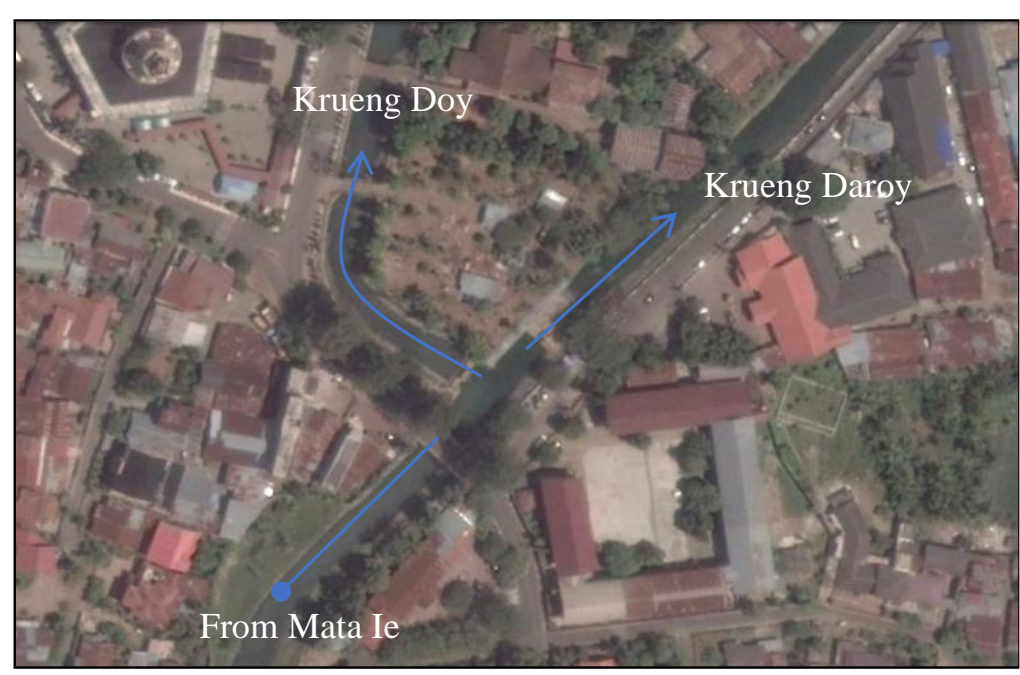

Figure 2. The branch of the river Source: Google Earth, 2021

The story about the goodness of Krueng Daroy's water is not only mentioned in Bustanussalatin. Some explorers also note that the river's water was highly pristine. Many people came down to bathe in this river to treat their wounds due to beheading and other punishments. Likewise, sick people believe that by drinking the water, they will be healthy again. As Agustinus De Beaulieu notes, "They didn't even put medicine other than rushing to wash their wounds in the river. They will let the wound keep bleeding for some time, wash it, stop it, and bandage it. Then they will be brought back home" (Reid 2010).

Francois Martin, a French trader who came to Aceh in 1604, said that the river water that flows through Daruddunya is obvious. This river originates from the mountains and then passes through the desert and beautiful trees such as camphor, cinnamon, sandalwood, and many other sweet trees. The locals argue that those trees maintain the quality of this water to be used as a healer (Reid 2010). The high quality of water might be one of the reasons why the Sultan diverged the river into his palace.

The location of this river in the middle of the Garden and other garden objects suggests that this river is one of the essential elements of the Garden. It was also written that the river bank was well made and covered with colourful stone. The riverbank was called Tebing Sangga Safa. In addition, two stone steps were made on the left and right of the river near the garden entrance, providing additional information that activities were being carried out directly on the river. Thomas Best, who came to Aceh in 1613, reported that he was invited to a banquet in the water as a welcoming after party.

"On May 2, 1613, he (Sultan Iskandar Muda) invited the delegation of the Queen of England, Thomas Best, to the bathing place, located about 5-6 miles from the Kraton. And sent me two elephants to take me and the supplies there. And we bathed in water; the King entertained us with a lavish banquet, all done in the water while soaking. All the wealthy and high-ranking officials of the king were present at the banquet. The feast lasted from 1 to 5 o'clock; the King invited me to leave half an hour after all the foreigners left. " (Reid 2005) 
The ritual of bathing or bathing in the river already exists and may have been passed down from the Acehnese ancestors, so having a canal flowing through the city is necessary for bathing activity.

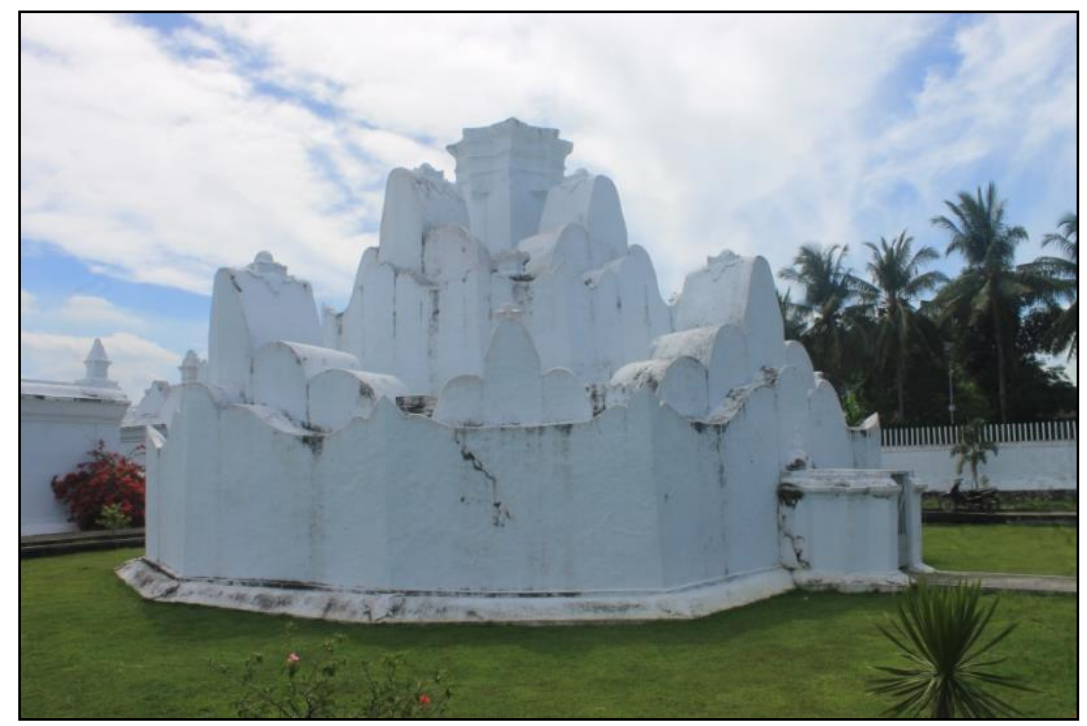

Figure 3. Gunongan in 2015

Source: Field Survey, 2015

Gunongan, one of the remnants that sit on the site, was mentioned in Bustanussalatin as Gegunongan Menara Permata (Figure3). The artificial mountain that has sparked historians' debate had pillars made of copper, a roof made of silver, and at the top, there was suasa, a mixture of gold and copper metals. There were also various gems in the artificial mountain whose exact location is not stated in the Bustanussalatin. Besides that, there was also a cave whose door was made of silver. The hill was overgrown with flowers. The Bustanussalatin manuscript also mentions the function of the mountain as a place to sit or sit in silence.

When someone enters the gate of Gunongan, someone will face a hallway, which is similar to a cave. This gate may be what Bustanussalatin meant as the entrance to the shelter. After climbing the stairs in the cave, someone then reached a hole that led him to the second floor, which was mostly covered with grass. Before reaching the spot, the stairs that took someone to the second floor turned to the left, so that right at the hole, someone is faced with the choice of going around the second floor through the left or right. The first area reached on the second floor is made of stone which is the cave's roof, and the rest of the second level is soil covered by grass.

Turning right from the point where someone first reached the second floor, someone found a considerable difference in height between the stone-faced floor and the grass floor, about $60 \mathrm{~cm}$. The author thinks that this position may not be the position to go down to the grassy floor because if someone turns to the left, someone finds a ladder to go down to the grass floor, and near the ladder, there is another ladder) towards the third floor. 
When someone comes out of the hole, then walks to the left, goes down a few steps, and will find a gallery. This gallery leads down the same path to the spot where the second floor rises, but before reaching the hole point, one is faced with a barrier. The barrier is possible to climb but not easy. Also, the grass on the second floor led the author to think that the plants mentioned in Bustanussalatin might have grown in this area. So that the second floor is not entirely used for walking, but only the part of the paved stone and a small path leading to the stairs to the third floor.

The third floor is entirely made of stone. This floor is right at the foot of the central pillar of Gunongan, which cannot be reached to the top. The highest part that can be called in Gunongan is this floor. On the third floor, stairs connect the three areas. Each area consists of a stone shaped like a flower.

Each passable path of the Gunongan led someone to the flower-shaped stones found in Gunongan (Figure 4). Wessing stated that these formations resembled gems and flowers that served as seats (Wessing, 1988: 165). Gunongan also has flower ornaments with a similar structure but vary in size, appear eight on the second floor and four on the third floor. The shape of the central pillar of Gunongan also shows the formation of large flowers. At the lower part of Gunongan, floral motifs appear on the eight corners Gunongan (Figure 5). Meanwhile, at the head of the cave, another carving was found that was different from the shape of other flowers in Gunongan (Figure 6).

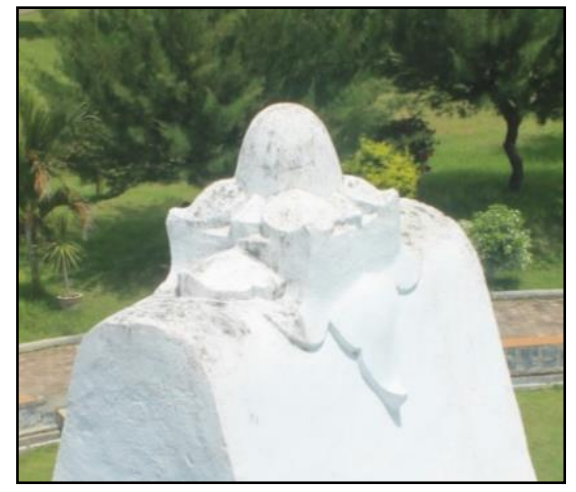

Figure 4. a Flower ornament in Gunongan Source: Field Survey, 2015

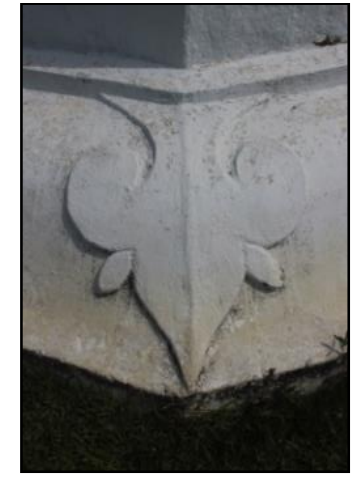

Figure 5. an Ornament at the lower part of Gunongan Source: Field Survey, 2015

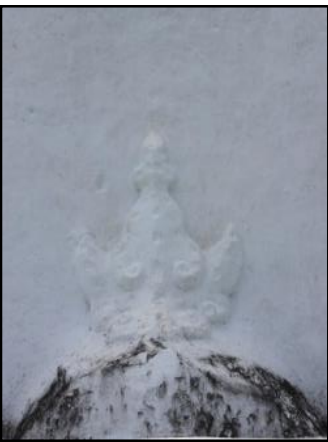

Figure 6. an Ornament at the head of the cave Source: Field Survey, 2015 
According to Bustanussalatin, near the Gegunungan Menara Permata (Gunongan), there is Kandang Baginda (Raniri and Iskandar 1966). Nowadays, Kandang Baginda is a white-walled building shaped like a courtyard on the south side of Gunongan. The enclosure is known as the final resting place of Sultan Iskandar Thani. The Kandang in Aceh is a tomb designation for the royal family. According to Wessing, Bustanussalatin did not mention that there was the tomb of Sultan Iskandar Thani (Wessing 1988). It was only said that the place was 'Kandang Baginda' and noted that Balai Gading was in front of the Kandang where the Sultan usually performed Khanduri (Wessing 1988).

The opinion that the building was his tomb may come from the writings of de Graff, who attended the funeral of Sultan Iskandar Thani. According to de Graff, Iskandar Thani was buried near the graves of his ancestors in the back yard of the palace (Lombard 1986). The argument was reinforced by discovering several Acehnese gravestones in the building, now stored at the Gunongan Complex Management Office. During an unpublished excavation in 1976, human remains and several gold plates were found in a coffin in the centre of the Kandang (Wessing 1991) (Figure 7). Lombard argues that this building could be the remaining part of the tomb complex of kings after the war destroyed the palace complex (Lombard 1986).

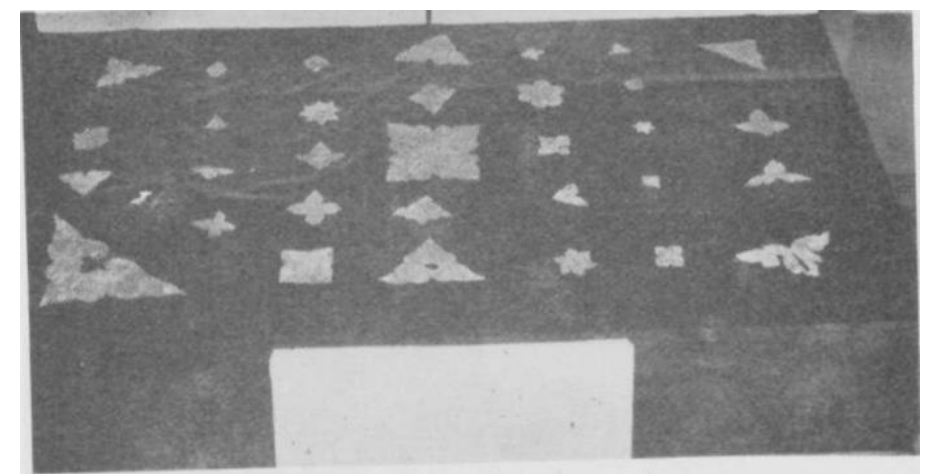

Figure 7. Gold plates found on the coffin in the centre of the Kandang Source: Petunjuk Singkat Museum Negeri Aceh, 1982

Bustanussalatin continues the description of the Kandang by mentioning that the structure has a white fence. This fence is different from the garden fence discussed earlier. The fence is carved in various colours. The author found many carvings around the fence. The full bloom is white, which may result from the paint colour that has faded, and over time the knowledge of these colours is lost so that the colour is uniformed with the wall colour.

On the inside, there could be a building with wooden pillars. The roof consisted of two layers of different colours, and the top was made of gold. There were tendril carvings at each end of the roof, and under them were hanging mirrors. However, the buildings inside are no longer visible today, possibly destroyed due to the Dutch attacks or lack of maintenance. A colonial photograph (see Figure 8) shows a big tree was grown inside the Kandang. This large tree was likely Bak Nawaih (Ricinus communis) or Bak Keulundong (Lannea coromandelica), which is commonly planted 
by the Acehnese on the head and foot of the tomb before giving the tombstone (Pula Batee Tradition).

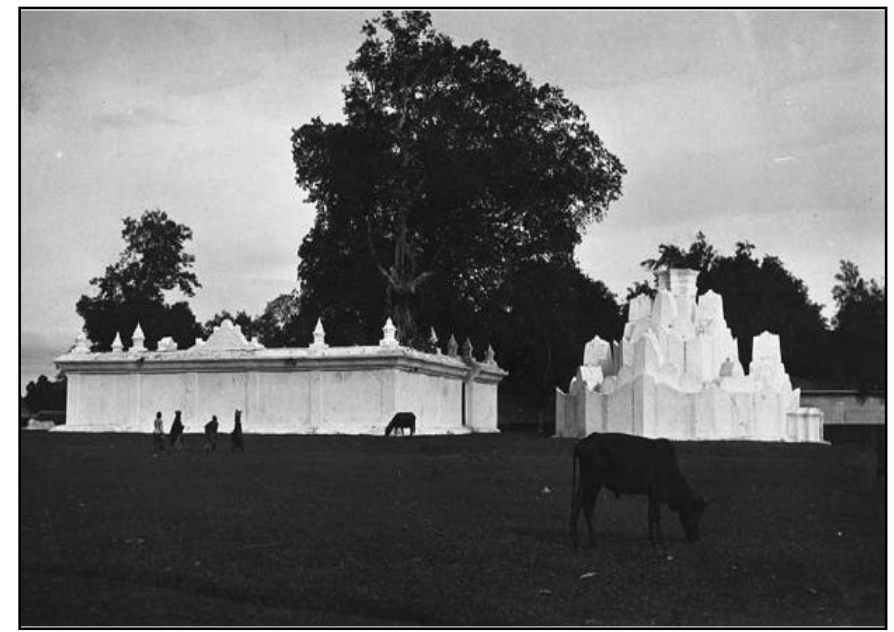

Figure 8. Kandang and Gunongan in the colonial era Source: collectie.tropenmuseum.nl, 1910-1926

\section{The Disappearance of Garden}

During the Dutch attack in 1874, the garden area was used for defence purposes, including the Kota Gunongan, Kota Koeboeran Radja, Kerkhoff Peucut, Kota Rantang, or Blang Padang Field. According to Arif (2014), soon after the palace occupation, the architectural order of the significant, meaningful, and beautiful Garden was destroyed by the Dutch by creating a new road and railway for military purposes in the new colonial town. Since then, the physical existence of the sultanate palace and the Garden was gradually diminished. In the early twentieth century Dutch maps, both urban forms are absent.

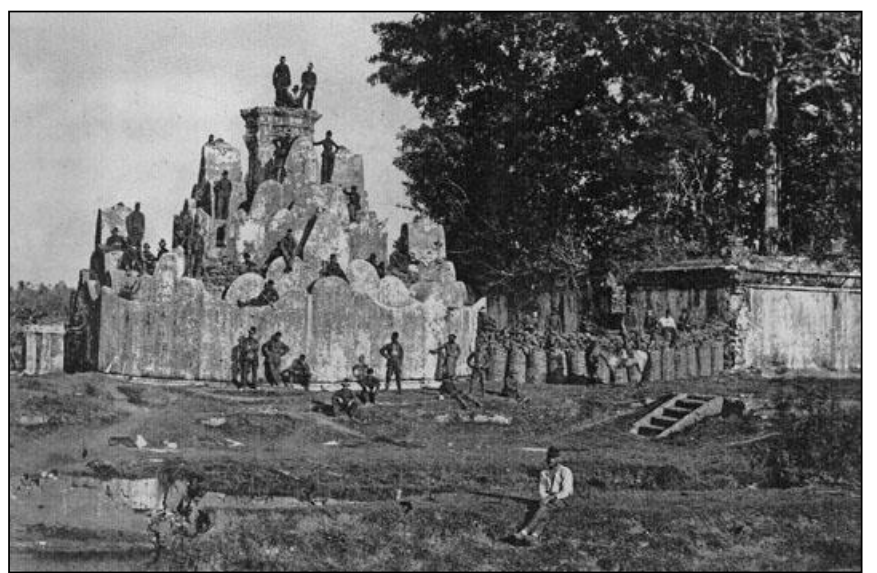

Figure 9. Dutch Troops standing in Gunongan after successfully taking control of the royal palace Source: Tropenmuseum 1880-1895 
A Dutch map of Aceh in 1873 is based on information from a traitor in the Kingdom of Aceh, Tengku Muhammad Arifin, who was a descendant of the king of the Moko Moko kingdom in Bengkulu who married the nephew of the Sultan of Aceh (Nur 2017). He might have been the one who could enter the deepest parts of the palace. The map based on his information does not draw the Garden in the southern part of the palace. In Figure 10, instead of drawing a garden, the mapmaker wrote jungle and paddy fields in the south part of the palace.

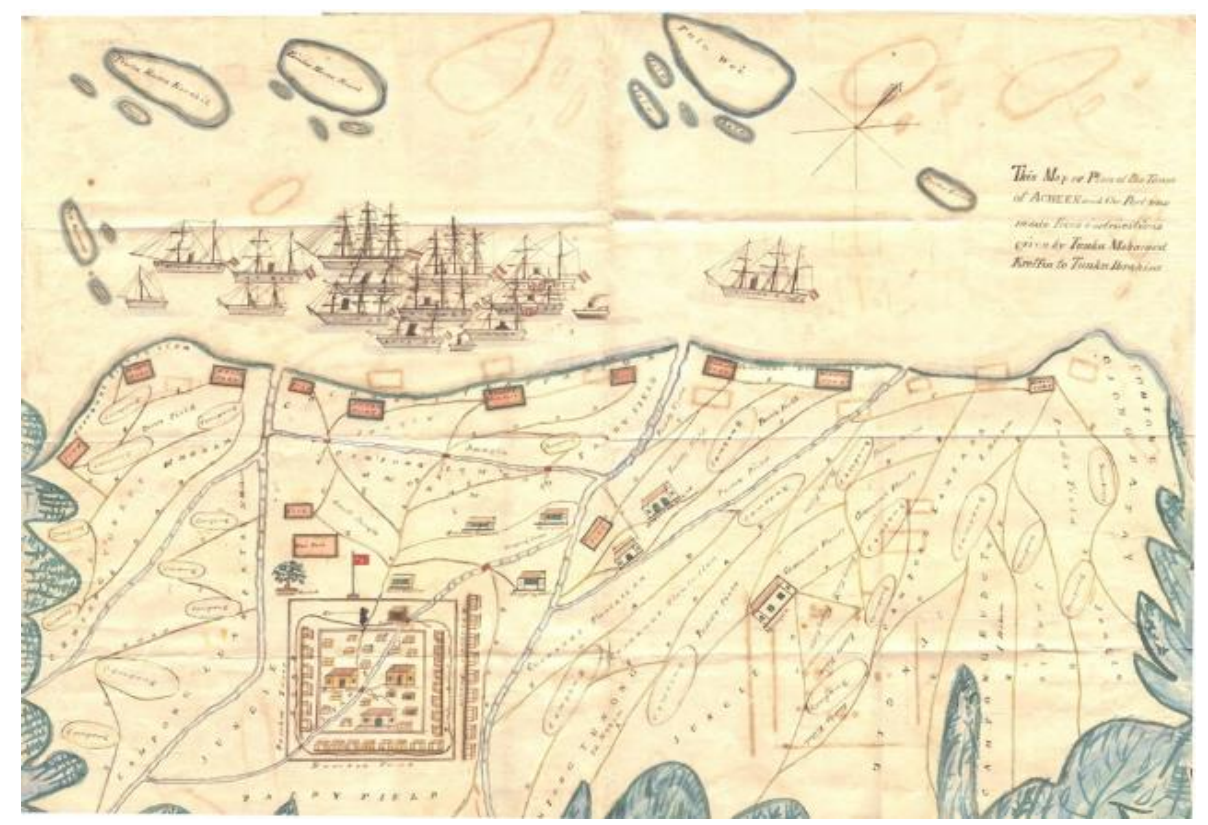

Figure 10. A Dutch map of Aceh in 1873

Source: Nur, 2017

On the map, the Krueng Daroy river is seen. It flows throughout the palace. While the area on the left and right side of the river, which should be the Garden, has turned into Jungle and Paddy Field. Here, the authors may assume that the Taman Ghairah was no longer there or maintained during this period.

In Bustanussalatin, it is stated that the Taman Ghairah consisted of various flower and fruit plants. Those garden plants need regular maintenance to keep the garden-like atmosphere of the Taman Ghairah. However, Lombard (1967) and Khan (2011) have described how the sultanate of Aceh faces monetary and political crises just after the death of Iskandar Thani. The problem might have affected the decrease in city beautification spending, which includes garden maintenance. In the nineteenth century, the Garden might have been lost because of the sultanate's monetary problem. So that, when Tengku Muhammad Arifin, the traitor, visited the Garden, he caught an impression of a forest, villages, and rice field rather than a pleasure garden. Another possible reason for the loss of the Garden is the changing focus of the sultanate. During the era of sultana (second half of the seventeenth century), the sultanate 
focused on other issues rather than the beautification of the royal enclosure, such as in the education and defence sector (Khan 2017).

\section{CONCLUSIONS}

From the literature review and artefact analysis, it can be concluded that the Taman Ghairah was built during the reign of Iskandar Muda and later was improved by Iskandar Thani, his successor. This Garden's idea could have been started when Iskandar Muda built the Krueng Daroy Canal and then built its riverbank. Thani, who made other elements of the Garden, was continued this effort and named the Garden Taman Ghairah.

During the sultana era, the Garden was not mentioned in the literature. During this era, sultanas were reported doing leisure activities such as bathing in the pond and family picnics. Those activities might have been done in some part of the Garden. Even though it still exists during sultanas' reign, this Garden's significance might have gradually diminished for several reasons. Firstly, the sultanate's economic condition and the internal conflict between the sultanate's descendants. The 1873 map of Aceh, just before the Aceh Dutch War, shows that this Garden was absent. This map opposed the previous beliefs that this Garden was absent during the Dutch Invasion after defeated the sultanate. The remain architectural objects, such as Gunongan, Pintô Khôp, Kandang, and the Leusong, might be preserved by the Dutch for fortification purposes and monuments.

\section{REFERENCES}

Arif, K. A. (2008). Ragam Citra Kota Banda Aceh: Interpretasi Sejarah, Memori Kolektif dan Arketipe Arsitekturnya. Pustaka Bustanussalatin, Bandung.

Arif, K. A. (2014). Citra Surga. The Atjeh. Nurlis E. Meuko. 4, Banda Aceh.

AS, N. (2014). Taman Ghairah Pada Masa Kerajaan Aceh. Jurnal Adabiya Fakultas Adab dan Humaniora UIN Ar-Raniry Banda Aceh 16(31).

Fadhil, M. N. (2015). Taman Ghairah Aceh: Simbol Arsitektur Pra-Islam dalam Taman Islam. Universitas Indonesia.

Fakriah, N. (2021). Islamic Garden Concept In Bustanussalatin (Garden Of The Kings), Aceh, Indonesia. Journal of Islamic Architecture, 6(3), 196-202. https://doi.org/10.18860/jia.v6i3.10840

Feener, R. M. (2011). The Acehnese Past and Its Present State of Study. Mapping the Acehnese past. R. M. Feener, P. T. Daly and A. Reid. KITLV Press, Leiden.

Harun, J. (2004). Bustan Al-Salatin, 'the garden of kings': A universal history and $A D A B$ work from seventeenth-century ACEH. Indonesia and the Malay World, 32(92), 21-52. https://doi.org/10.1080/1363981042000263444

Iskandar, T. (1966). Bustanussalatin Bab II Fasal 13. Percetakan Bahasa dan Pustaka.

Khan, S. B. A. L. (2011). The jewel affair: The sultana, her orang kaya and the Dutch foreign envoys. Mapping the Acehnese Past. R. M. Feener, P. T. Daly and A. Reid. Leiden, KITLV: 141-162. 
Khan, S. B. A. L. (2017). Sovereign Women in a Muslim Kingdom: The Sultanahs of Aceh, 1641-1699. NUS Press, Singapore.

Lombard, D. (1967). Le Sultanat D'Atjéh au Temps D'Iskandar Muda 1607-1636. Ecole Française d'Extrême-Orient, Paris.

Lombard, D. (1986). Kerajaan Aceh Zaman Sultan Iskandar Muda (1607-1636). Balai Pustaka, Jakarta.

Lombard, D. (2006). Kerajaan Aceh zaman Sultan Iskandar Muda (1607-1636) / Denys Lombard ; diterjemahkan oleh Winarsih Arifin ; kata pengantar oleh Henri Chambert-Loir. Kepustakaan Populer Gramedia, : Forum Jakartas-Paris, : Ecole francaise d'Extreme-Orient, Jakarta.

Manguin, P.-Y. (1999). Demografi dan Tata Perkotaan di Aceh Abad 16 Data Baru Menurut Sebuah Buku Pedoman Portugis Tahun 1584. Panggung Sejarah : Persembahan kepada Prof. Dr. Denys Lombard. H. Chambert-Loir and H. M. Ambary. Jakarta, Yayasan Obor Indonesia: 225-244.

Nur, I. M. (2017). "Map of treason in 1873." Retrieved 13 February 2020, 2020, from https://steemit.com/history/@vannour/map-of-treason-in-1873.

Raap, W. R. (1994). The Great Mosque of Banda Aceh: its history, architecture and its relationship to the development of Islam in Northern Sumatra. UMI Dissertation Services, Michigan.

Raniri, N. a.-D. and T. Iskandar (1966). Bustanus-salatin : bab 2, fasal 13. DBP, Kuala Lumpur.

Reid, A. (2005). An Indonesian Frontier: Acehnese \& other histories of Sumatra / Anthony Reid. Singapore University Press, Singapore.

Reid, A. (2010). Islam in South-East Asia and the Indian Ocean littoral, 1500-1800: expansion, polarisation, synthesis. The New Cambridge History of Islam. D. O. Morgan and A. Reid. Cambridge University Press, Cambridge.

Restiyadi, A., \& Syam, A. I. (2018). Gaya ornamentasi gunongan the gunongan's ornamentation style. Berkala Arkeologi Sangkakhala (BAS), 21(1), 16-34.

Wessing, R. (1988). "The Gunongan in Banda Aceh, Indonesia: Agni's Fire in Allah's Paradise?" Archipel 35: 157-194.

Wessing, R. (1991). "An Enclosure in the Garden of Love." Journal of Southeast Asian Studies 22(1): 1-15.

Wulandari, E., Soetomo, S., Syahbana, J. A., \& Manaf, A. (2017). The Ecology Character Of Banda Aceh City In The 17th Century. Journal of Islamic Architecture, 4(3), 93. https://doi.org/10.18860/jia.v4i3.3872 
Fadhil, Fakriah: THE LOST GARDEN OF ACEH

This Page is Intentionally Left Blank 